\title{
初期乾燥充填層における液ホールドアップに及ぼす チャネリングファクターの影響
}

\section{一初期乾燥充填層における液ホールドアップの推算式一}

\author{
川端 弘俊* ・新名 和也 $* 2$ ・原田 武士 $* 3 \cdot$ 碓井 建夫*
}

Influence of Channeling Factor on Liquid Hold-ups in an Initially Unsoaked Bed

Hirotoshi Kawabata, Kazuya Shinmyou, Takeshi Harada and Tateo Usul

Synopsis : One of the important factors for minimum energy consumption and $\mathrm{CO}_{2}$ emission of a blast furnace (BF) is to elucidate the liquid flow phenomena and liquid hold-ups in the dripping zone of BF. Liquid hold-ups were studied by using a cold model of a fixed bed soaked prior to experiments (hereinafter called initially soaked bed), but the existing correlation equations derived from liquid hold-ups under initially soaked bed do not agree with liquid hold-ups under initially unsoaked bed such as the dripping zone of BF.

In the present study, correlation equations for liquid hold-ups in initially unsoaked bed were experimentally derived by a new approach, in which channeling factor $\left(\mathrm{F}_{\mathrm{C}}\right)$ was proposed and defined as follows: $\mathrm{F}_{\mathrm{C}}$ is the ratio of the number of liquid paths per one horizontal line to the number of voids between particles per the same horizontal line, and was measured by using the moving image of liquid paths photographed by a CCD video camera.

By using empirical equation for $\mathrm{F}_{\mathrm{C}}$, hold-ups in initially unsoaked bed were described as the following correlation equations.

Static hold-up $\quad \mathrm{H}_{\mathrm{S}(1-\mathrm{UB})}(\%)=0.9 \cdot \mathrm{H}_{\mathrm{S}(1 \mathrm{SB})} \cdot \mathrm{F}_{\mathrm{C}}^{0.8} \cdot N c_{m}^{-1}$

Dynamic hold-up $\mathrm{H}_{\mathrm{d}(1) \mathrm{UB})}(\%)=0.9 \cdot \mathrm{H}_{\mathrm{d}(1 \mathrm{SB})} \cdot \mathrm{F}_{\mathrm{C}}^{0.5}$

Total hold-up is the sum of $\mathrm{H}_{\mathrm{S}}$ and $\mathrm{H}_{\mathrm{d}} \quad \mathrm{H}_{\mathrm{t}}(\%)=\mathrm{H}_{\mathrm{S}}+\mathrm{H}_{\mathrm{d}}$

where, $N c_{\mathrm{m}}=1+(\cos \theta)^{3}$, and subscripts I-SB and I-UB designate quantities associated with initially soaked and unsoaked beds, respectively.

The comparison with the previous liquid hold-ups shows that the estimated hold-ups are in good agreement with the experimental values for any particle diameters used and both contact angles of $10^{\circ}$ and $70^{\circ}$ under initially unsoaked bed.

Key words: channeling factor; empirical equation; initially unsoaked bed; liquid hold-up; liquid path; blast furnace.

\section{1. 緒言}

エネルギー使用・ $\mathrm{CO}_{2}$ 排出極少化の革新的高炉開発を目 指して多くの研究が行われている。高炉滴下带における液 流れ現象や液ホールドアップの解明もそれらの開発には欠 かせない重要な要素研究の一つである。

これまで液ホールドアップに関する多くの実験・研究 は，実験前の充填層内が十分湿潤した状態すなわち初期湿 潤充填層(Initially soaked bed)における固定層コールドモデ ル (-5)に基づいて行われてきた。しかしながら，高炉滴下 带では充填物が十分濡れた状態でないことから実験前の充 填層が乾燥している初期乾燥充填層 (Initially unsoaked bed) を用いて実験を行うべきであり，初期乾燥充填層における
液ホールドアップ (6-10) は初期湿潤充填層の值と異なること も判明されつつある。また著者ら ${ }^{8.10)}$ が 1 次元コールドモ デル（1Dモデル）を用いて行った実験結果から，以下の ようなことが判明した。濡れにくい系の初期湿潤充填唐に おいては，全ホールドアップ，静的ホールドアップ，動的 ホールドアップは充填粒子径の減少すなわち固体の比衣俑 積の増加とともに単調に増加する。また，初期湿澗光媜间 の液ホールドアップの測定值は液ホールドアップの推算 式，例えばFukutakeと Rajakumar ${ }^{3} の$ 式から計算した佔と 致する。一方，濡机にくい系の初期乾燥充填層においては， 全ホールドアップと静的ホールドアップは粒子径の減少と ともに増加し，粒子径が $10 \mathrm{~mm}$ 付近で最大值を取る。さら に粒子径が減少すると比表面積がさらに増加するにも関わ

原著碖文：ISIJ Int., Vol. 45 (2005), No. 10,pp. 1474-1481

平成 18 年 4 月 27 月受付平成 18 年 6 月 5 日受理 (Received on Apr. 27, 2006; Accepted on June 5, 2006; originally published in ISIJ Int., Vol. 45, 2005, No. 10, pp 1474-1481)

* 大阪大学大学院 L学研究科マテリアル生産科学専攻 (Department of Materials and Manufacturing Science, Graduate School of Engineering, Osaka University, 2-1 Yamadaoka Suita 565-0871)

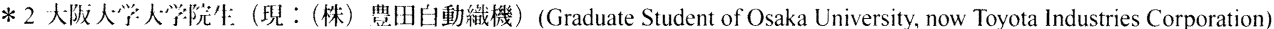

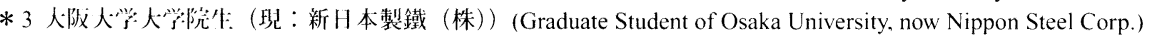


らず全ホールドアップと静的ホールドアップが急激に減少 する特異な現象を示す。このように濡れにくい系の液ホー ルドアップに及ぼす充填層初期乾湿状態の影響は非常に大 きく，また，既存の液ホールドアップの推算式3)では初期 乾燥充填層の液ホールドアップ值を推算できない。

本研究では, 初期乾燥充填層における液ホールドアップ の推算式を導出するために，充填層内液流机挙動に関する 詳細な可視化実験結果からチャネリングファクター $\left(\mathrm{F}_{\mathrm{C}}\right.$ : 液流れの偏流度合すなわち液滴と粒子との接触効率 に関する因子）を提案し，かつ $\mathrm{F}_{\mathrm{C}}$ を CCDビデオカメラを 用いた可視化実験により求めた。その $F_{C}$ と初期乾燥充填 層における多くの液ホールドアップデータを用いて回帰解 析により液ホールドアップの推算式を導出した。

\section{2. 実験}

\section{$2 \cdot 1$ 初期乾燥充填層における液流路の可視化}

初期乾燥充填層における $\mathrm{F}_{C}$ 安実験的に導出する目的, および液流れ挙動を詳細に調査するために可視化方法を用 いた。可視化実験に用いた充填容器は，Fig. 1に示したよ うに内寸法が幅 $400 \mathrm{~mm}$, 奥行き $100 \mathrm{~mm}$ ，高さ $400 \mathrm{~mm}$ の 直方体で，透明アクリル製の 2 次元可視化コールドモデル (2D 可視化モデル) である。粒子は $175 \mathrm{~mm}$ の高さまで充 填した。液体は，ダイアフラムポンプを用いて内径 $0.5 \mathrm{~mm}$, 長さ $25 \mathrm{~mm}$ の注射針 773 本を持つ液分散器に压入 し, 充填層層頂から均一に滴下した。液体には, 液流路を 見やすくするために赤インクで着色した水道水を用いた。 液流れ挙動と液流路は充填層前面から CCD ビデオカメラ で連続撮影した。またデジタルカメラも併用した。

液流れ分布抢よび液ホールドアップに及ぼす壁面の影響 を小さくするために，内壁面はフッ素被覆した。使用した

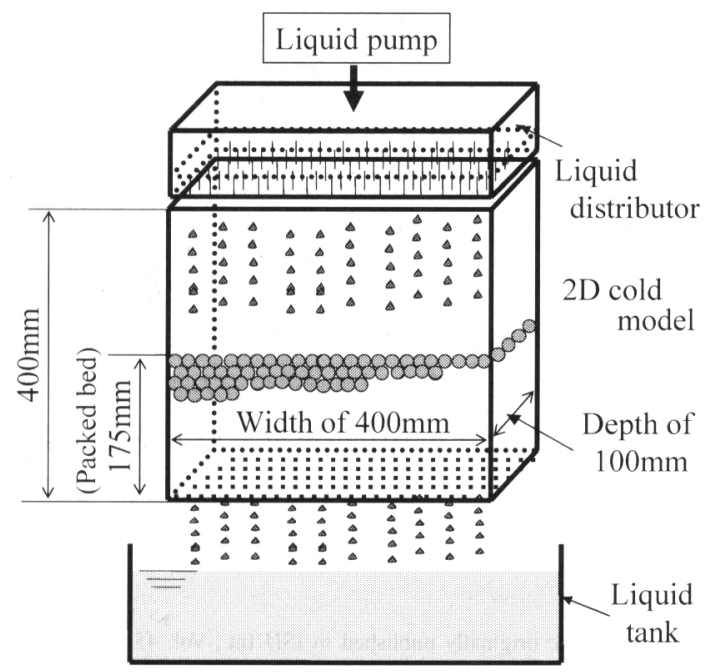

Fig. 1. Schematic layout of the two-dimensional model for visualization of liquid flow behavior and measurement of channeling factor (transparent acrylic resins).
充填粒子の大きさは6種類で, 直徍 $\left(D_{p}\right) 2.8,5.0,8.1,10.3$, 15.1 と $19.4 \mathrm{~mm}$ のアルミナ球である。固液接触角 $(\theta)$ は フッ素被覆した粒子を用いた濡れにくい系が $65^{\circ}$ であり フッ素被覆していない粒子を用いた濡れやすい系が50で ある。Table 1 に示したように, これらの粒子を2D可視化 モデルに充填した時の空隙率 $(\varepsilon)$ は， $D$ が 2.8 から $19.4 \mathrm{~mm}$ へと大きくなるとともに $\varepsilon=0.35(-)$ から 0.40 まで増加す る。また平均空隙直径 $\left(d_{v}=[\varepsilon /(1-\varepsilon)]^{1 / 3} \cdot D_{p}\right)$ も 2.3 から 16.9 $\mathrm{mm}$ へと大きくなる。

\section{$2 \cdot 2$ チャネリングファクターの定義と測定方法}

初期乾燥充填層における液ホールドアップの推算式を導 くために提案したチャネリングファクター $\left(\mathrm{F}_{\mathrm{C}}\right)$ は次のよう に定義した。 $\mathrm{F}_{C}$ は, 充填層の一つの水平断面上に形成さ れる液流路（液滴や細流流れ）の本数と同じ水平断面上に 括ける粒子一粒子間の隙間の数との比（Fig. 2参照）であ り, 液と接触する有効粒子割合を意味する。 $\mathrm{F}_{\mathrm{C}}$ の測定方 法は有効接触面積の直接測定と比較して非常に簡単であ る。Fig. 2に示したように，充填層を水平に4分割した $3 つ$ の水平線 $\mathrm{A}, \mathrm{B}, \mathrm{C}$ に打いて, 液流路の本数と粒子間の空 隙の数（ほほ粒子数と同じ）を測定した（カラー写真を白 黒変換しているので, ピンク色の液滴や細流は死色から黒 く見え，白っぽく丸いのが球形の充填粒子である）。3 の水平ライン上に打ける $\mathrm{F}_{\mathrm{C}}$ の平均值を $\mathrm{F}_{\mathrm{C}}$ 值 $(\leqq 1)$ と定義し た。

初期乾燥充填層に打ける $\mathrm{F}_{\mathrm{C}}$ を測定するために，液の滴 下開始と同時にCCD ビデオカメラで充填層の液流れ挙動 を2D可視化モデル前面から $10 \mathrm{~min}$ 間連続撮影した。また， 静止画像もデジタルカメラで撮影した。実際の $\mathrm{F}_{\mathrm{C}}$ 測定は, CCD ビデオカメラで撮影した動画をパーソナルコン ピュータの画面上で4倍速に再生し, 液の滴下開始から5 $\min$ 後すなわち充填層内の液流れが定常状態に到達した後 から $10 \mathrm{~min}$ までの $5 \mathrm{~min}$ 間に液滴や細流が通過するか否か を（繰り返し同じ所を液が流下しても1本，一度でも流下 すれば 1 本), 充填層を水平に 4 分割した 3 つの水平線上に おいて計数した。測定制度を向上させるために, その計数

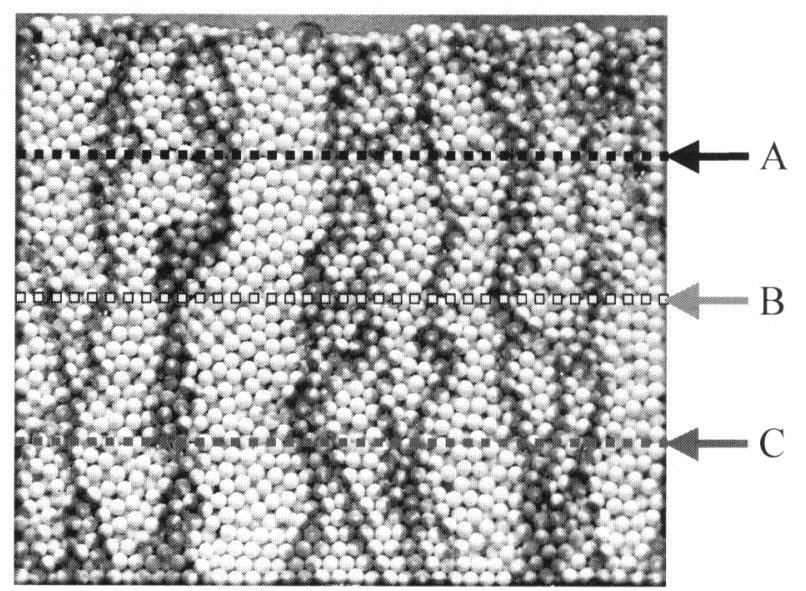

Fig. 2. Measurement method of channeling factor. 
を2,3回繰り返し，3つの水平線上での計数值の平均值を $\mathrm{F}_{\mathrm{C}}$ 值とした。

\section{3. 結果}

\section{3 . 1 初期乾燥充填層における液流れ挙動の可視化}

Fig. 3は，初期乾燥充填層に打いて，濡扎にくい系 $\left(\theta \fallingdotseq 65^{\circ}\right)$ の $D_{p}=2.8,5.0,10.3$ と $15.1 \mathrm{~mm}$ 球充填層における可 視化写真の一例を示している。なお，空塔液速度 $\left(V_{L}\right)$ は $0.1 \mathrm{~mm} / \mathrm{s}$ 一定である。Fig. 3より， $D_{p}=2.8$ と $5.0 \mathrm{~mm}$ の充填 層内において，充填層頂部より均一分散した液滴が特定の 液流路や細流を形成しており ${ }^{7.10)}, D_{p}=2.8$ では3，4本， $D_{p}=5.0 \mathrm{~mm}$ では 10 本程度の流路が確認できる。一方， $D_{p}=10.3$ と $15.1 \mathrm{~mm}$ の充填層では, 液滴や細流は充填層全 体に渡り粒子間や粒子表面上にほぼ均一に分散している。

Fig. 4は，初期乾燥充填層の濡れやすい系 $\left(\theta \fallingdotseq 5^{\circ}\right)$ におけ る可視化写真の一例である。 $D_{p}=5.0,10.3,15.1$ と $19.4 \mathrm{~mm}$ であり， $V_{L} \fallingdotseq 0.1 \mathrm{~mm} / \mathrm{s}$ 一定である。濡れやすい系の充填層 上部においては，液滴が充填粒子と十分濡れて括り，粒子 間や粒子表面上によく広がっているのが分かる。充填層内 における $D_{p}=5.0 \mathrm{~mm}$ の液流路は 3,4 本， $D_{p}=10.3 \mathrm{~mm}$ は 7 本程度であり，初期乾燥充填層における液流路の数より少 ない。さらに， $D_{p}=15.1$ あるいは $19.4 \mathrm{~mm}$ と充填粒子が大 きくなっても，液滴や細流は特定の流路を形成しながら流 下し，充填層全体に広がっていないことがよく分かる。

濡れる系では液滴は粒子表面に広がりやすいにも関わら ず，初期乾燥充填層の層頂から充填層に均一分散した液滴 は，充填層全体には広がらずに局所的な流路を形成しなが ら流下している。Li ${ }^{11,12)}$ も「親水系の小粒子充填層の場 合，毛細管力の増加により液流れは簡単に合流し，チャネ リングフローが形成される。と報告している。このよう
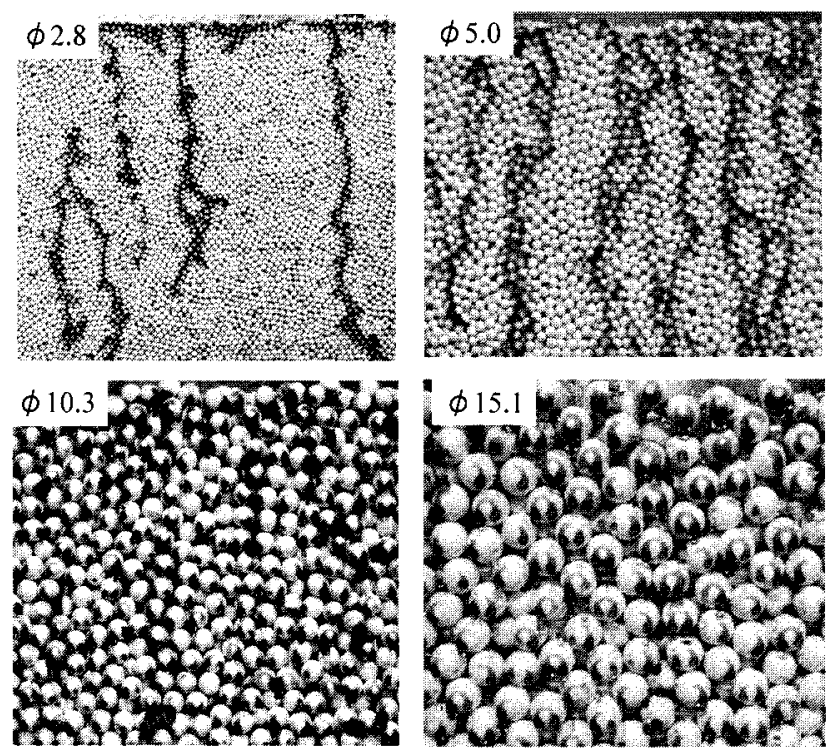

Fig. 3. Visualization of liquid flow behavior under initially unsoaked bed with bad wettability $\left(\theta \doteqdot 65^{\circ}\right)$.
に，初期乾燥充填層の液流れ挙動に及ぼす濡れ性の影響は 非常に大きい ${ }^{8,10)}$ 。

\section{$3 \cdot 2$ 初期乾燥充填層における $F_{\mathrm{C}}$ に及ぼす濡れ性の影響}

通常，容器径が粒子径より十分大きくない場合，壁面近 傍の空隙率 $\varepsilon$ は充填層内部の $\varepsilon$ より大きいので，液流れが 壁面近傍に集中し液流分布は不均一になる（いわゆる壁効

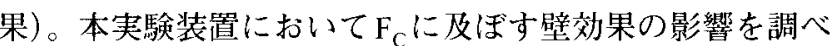
るために，充填層を支えるために設置した底板に開けた全 ての穴（幅方向に33ヶ所 $\times$ 奥行き方向に10ヶ所の穴）か ら液滴が滴下するか否かを観察し，奥行き方向の滴下分布 を滴下する穴の数と全ての穴の数との割合として求めた。 滴下穴の割合(Dripping hole rate) とは，横方向の穴の数 33 に対する液が滴下している゙穴の数の割合である。縦の列は No. 1 からNo.10まで10ヶ所奥行き方向に並んでいる。滴
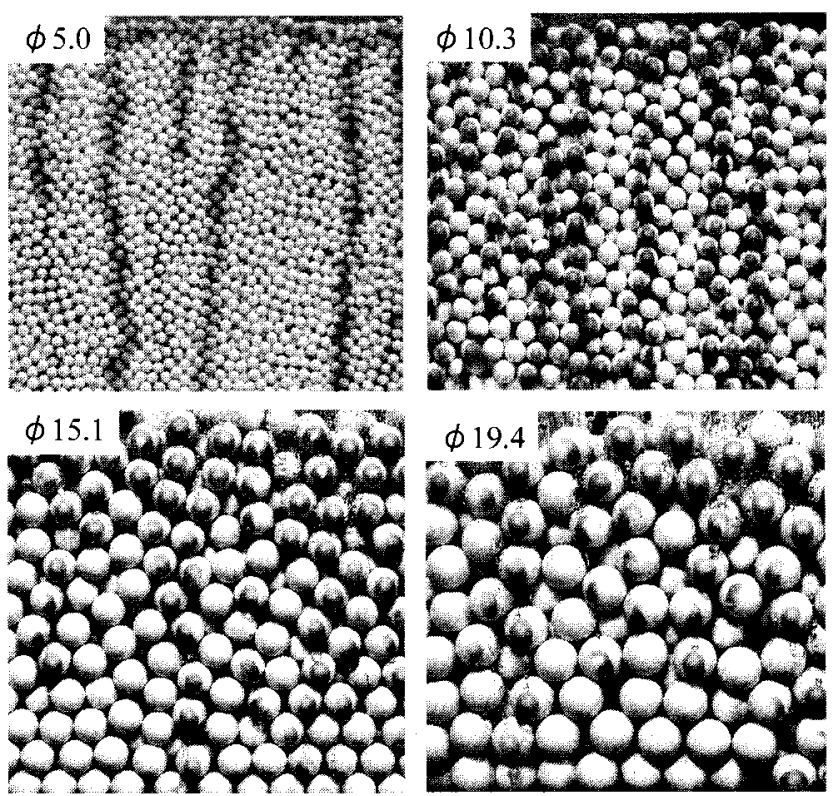

Fig. 4. Visualization of liquid flow behavior under initially unsoaked bed with good wettability $\left(\theta \fallingdotseq 5^{\circ}\right)$.

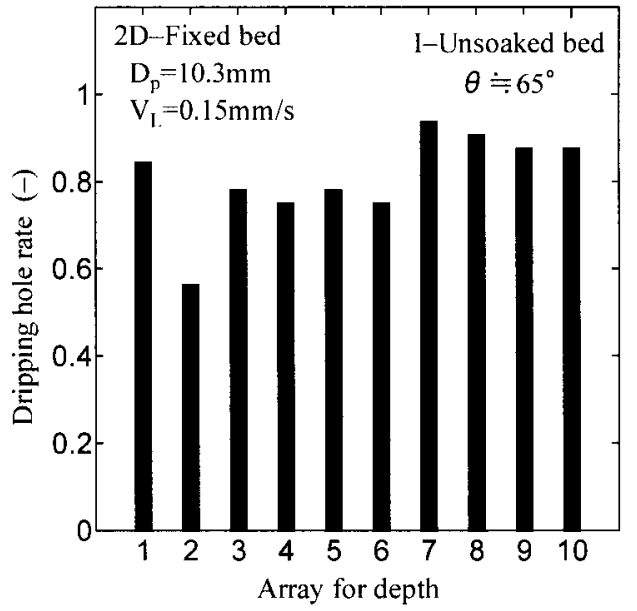

Fig. 5. Influence of wall surface on liquid dripping distribution (1: front side, 10: back side)

Where, dripping hole rate is the ratio of the number of dripping holes to the number of all holes for an array in the width direction. 


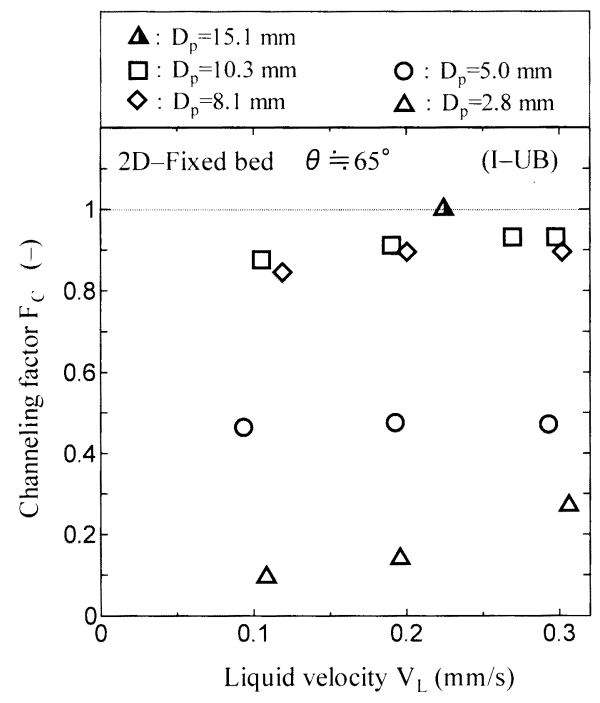

Fig. 6. Effect of liquid velocity on channeling factor under initially unsoaked bed with bad wettability $\left(\theta \fallingdotseq 65^{\circ}\right)$.

下穴の割合の奥行き方向分布を示したのが Fig. 5 である。 列No. 1 と No. 10 が前面と後面の壁近傍である。Fig. 5 に示 したように $\left(D_{p}=10.3 \mathrm{~mm}, \theta \fallingdotseq 65^{\circ}, V_{L}=0.15 \mathrm{~mm} / \mathrm{s}\right.$ の条件 $)$ ， 充填層下部からの液の滴下分布は前面から後面までほぼ一 定であることから，本実験装置では $\mathrm{F}_{\mathrm{C}} に$ 位す壁効果の 影響はほとんど無いと言える。他の粒子径の場合も壁効果 の影響はほとんど無かった。したがって，本実験装置のよ

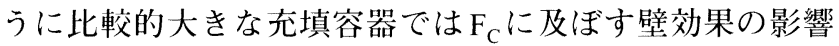
はほとんど無視できると考えられる。一方， $\theta \fallingdotseq 5^{\circ}$ の場合， $\mathrm{F}_{\mathrm{C}}$ 測定值のバラッキが大きく壁効果の影響は判別できな かった。

$\theta \fallingdotseq 65^{\circ}$ における $\mathrm{F}_{\mathrm{C}}$ に及ぼす $V_{L}$ の影響を Fig. 6に示す。 $\mathrm{F}_{\mathrm{C}}$ は， $D_{p}$ が 2.8 から $15.1 \mathrm{~mm}$ へと大きくなるとともに, 約 0.1 から 1.0 に増加する。また, $D_{p}=2.8 \mathrm{~mm}$ の場合を除いて $V_{l}$ の影響はほとんど無い。 $D_{p}=5.0 \mathrm{~mm}$ の $\mathrm{F}_{\mathrm{C}}$ は約 0.5 , $D_{p}=8.1$ あるいは $10.3 \mathrm{~mm}$ でほぼ 0.9 , そして $D_{p}=15.1 \mathrm{~mm}$ での $\mathrm{F}_{\mathrm{C}}$ は1.0の值である。

Fig. 7は $\theta \fallingdotseq 5^{\circ}$ の場合の $\mathrm{F}_{\mathrm{C}}$ に及ぼす $V_{L}$ の影響を示してい る。それぞれの $\mathrm{F}_{\mathrm{C}}$ 值は数回実験を行った平均值であるが $\mathrm{F}_{\mathrm{C}}$ に及ぼす $V_{L}$ の影響は明らかではない。 $\mathrm{F}_{\mathrm{C}}$ の実験式の導 出過程での解析を簡単化するために, 本研究の実験範囲で は $\mathrm{F}_{C}$ に及ぼす $V_{L}$ の影響は無いと仮定して，それぞれの $V_{L}$ に打ける平均値を $\mathrm{F}_{\mathrm{C}}$ 值とした。

\section{3 初期乾燥充填層におけるチャネリングファクターの 実験式}

Fig. 8 は, 接触角 $\theta$ をパラメータとして, チャネリング ファクター $\mathrm{F}_{\mathrm{C}}$ と平均空隙径 $\left(d_{\mathrm{r}}=[\varepsilon /(1-\varepsilon)]^{1 / 3} \cdot D_{p}\right)$ の関係を示

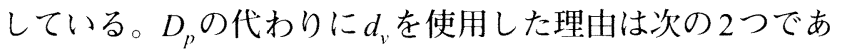
る。(1) 液滴や細流流れ挙動は主に充填層内の空隙径の 影響を受けるので $\mathrm{F}_{\mathrm{C}}$ は $D_{p}$ よりも $d_{v}$ により強く依存すると 考えられる。(2) 本可視化モデル装置においてをは $D_{p} か ゙$

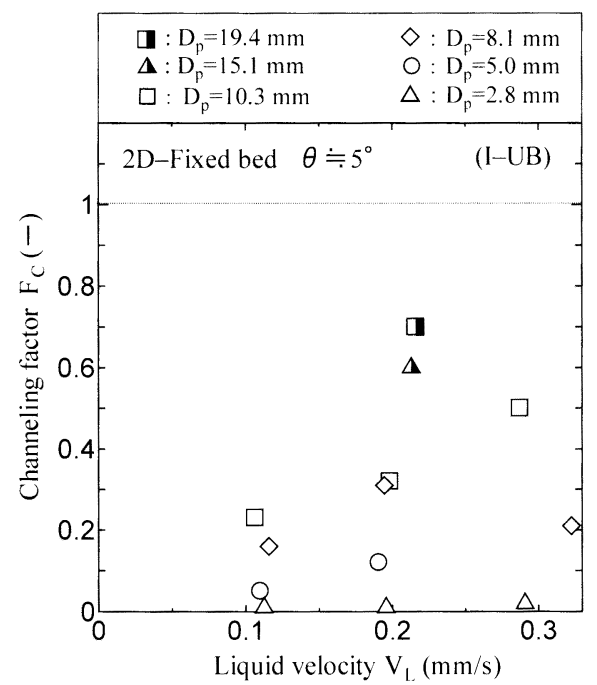

Fig. 7. Effect of liquid velocity on channeling factor under initially unsoaked bed with good wettability $\left(\theta \fallingdotseq 5^{\circ}\right)$.

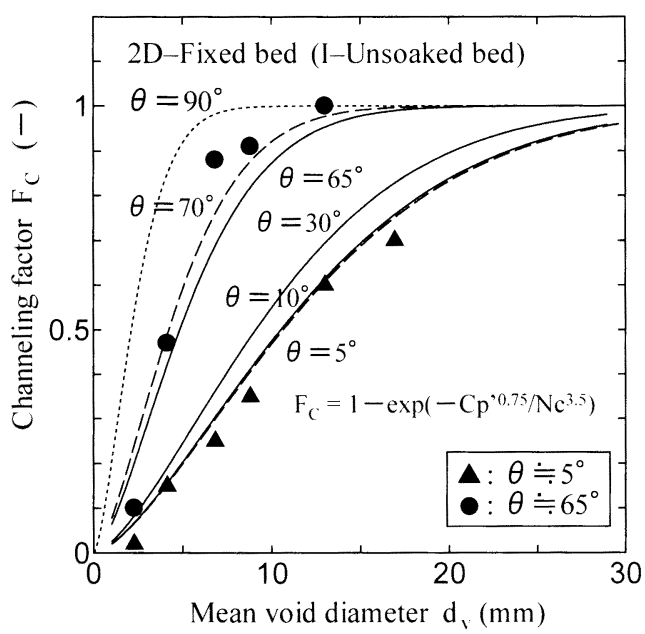

Fig. 8. Relation between channeling factor and mean void diameter under initially unsoaked bed.

Table 1. Particle diameter and void fraction of $2 \mathrm{D}$ visualization model $(400 \mathrm{~W} \times 100 \mathrm{D} \times 175 \mathrm{~mm} \mathrm{H})$.

\begin{tabular}{|c|c|c|}
\hline $\begin{array}{c}\text { article diameter } \\
\mathrm{D}_{\mathrm{p}}(\mathrm{mm})\end{array}$ & $\begin{array}{c}\text { Void fraction } \\
\varepsilon(-)\end{array}$ & $\begin{array}{c}\text { Mean void } \\
\text { diameter } \mathrm{d}_{\mathrm{v}}(\mathrm{mm})\end{array}$ \\
\hline 2.8 & 0.35 & 2.3 \\
\hline 5.0 & 0.36 & 4.1 \\
\hline 8.1 & 0.375 & 6.8 \\
\hline 10.3 & 0.385 & 8.8 \\
\hline 15.1 & 0.39 & 13.0 \\
\hline 19.4 & 0.40 & 16.9 \\
\hline
\end{tabular}

2.8 から $19.4 \mathrm{~mm}$ まで変化すると 0.35 から 0.40 まで増加す

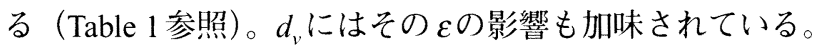
$\mathrm{F}_{\mathrm{C}}$ に及ぼす $V_{L}$ の影響は無いと仮定したので， $\mathrm{F}_{\mathrm{C}}$ は，そ

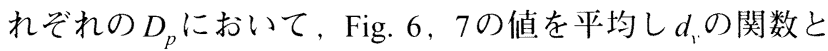
して $\theta \fallingdotseq 5^{\circ}$ と $65^{\circ}$ に対して Fig. 8 にプロットした。 $\mathrm{F}_{\mathrm{C}}$ は， $\theta$ 
に関わらず $d_{v}$ の増加とともに1に漸近することを考慮し， 回帰解析より $d_{v}$ と $\theta$ の関数として式(1)のように導いた。

$$
\mathrm{F}_{\mathrm{C}}=1-\exp \left(-C p^{0.75} / N \mathrm{C}^{3.5}\right)(-) \cdot
$$

ここで, $C p^{\prime}=\left[\rho_{L} \cdot g \cdot\left(d_{v}\right)^{2} / \sigma_{L}\right]$ は修正キャピラリー数 $(-)$, $\mathrm{Nc}=1+\cos \theta$ 海無次元界面力 $(-), d_{v}=[\varepsilon /(1-\varepsilon)]^{1 / 3} \cdot D_{p}$ は平均 空隙径 $(\mathrm{m}), g$ は重力加速度 $\left(\mathrm{m} / \mathrm{s}^{2}\right), \rho_{L}$ は液体の密度 $\left(\mathrm{kg} / \mathrm{m}^{3}\right)$, $\sigma_{L}$ は表面張力 $(\mathrm{N} / \mathrm{m}), \theta$ は固液接触角 $(\mathrm{deg}), \varepsilon$ は空隙率 $(-)$ である。

図中に示した実線，破線などの種々のラインは式(1)か ら計算した值であり， $\theta=5^{\circ}$ と $65^{\circ}$ に対する測定值は，式 (1)の計算值と比較的よく一致している。

\section{4. 考察}

\section{$4 \cdot 1$ 初期乾燥充填層における液ホールドアップの推算式 の導出}

$4 \cdot 1 \cdot 1$ 初期湿潤充填層における液ホールドアップの推 算式の微修正

本研究で用いた液ホールドアップデータは，より正確な 液ホールドアップを求めるために次のように微修正されて いる ${ }^{8.10)}$ 。静的ホールドアップは，充填層内に留まってい る液体積, すなわち粒子表面, 粒子一粒子間の隙間, 粒子一 壁間の隙間に滞留している液体積を空塔体積で除した值 (本研究では百分率表示) であるが，充填層内に留まった 液の質量を測定する方法では, 測定した静的ホールドアッ プ值に粒子が充填されていない場合でも内壁面や充填容器 底面に留まる液体量も含まれており，その值は充填塔の大 きさに依存する。したがって，それらの液体量は測定值か

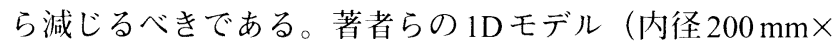
充填高さ $500 \mathrm{~mm}$ ) における空塔でのその值は $0.41 \%$ であ るので，粒子充填層の測定值から $0.41 \%$ を減じた值を $\mathrm{H}_{\mathrm{S}}$ と定義した。したがって, 初期湿潤充填層における液ホー ルドアップの推算式は, Fukutakeと Rajakumar ${ }^{3)}$ の推算式を 以下のように微修正した。

静的ホールドアップ（初期湿潤充填層 $(\mathrm{I}-\mathrm{SB})$ ),

$$
\mathrm{H}_{\mathrm{S}(1-\mathrm{SB})}(\%)=100 /\left(26+0.27 C p_{m}^{0.9}\right)
$$

ここで, $C p_{m}=C p_{s} / N c=\left[\rho_{L} \cdot g \cdot\left(D_{p}\right)^{2}\right] /\left[\sigma_{L} \cdot(1+\cos \theta) \cdot(1-\varepsilon)^{2}\right]$ は 修正キャピラリー数 $(-), C p_{s}=\left[\rho_{L} \cdot g \cdot\left(D_{p}\right)^{2}\right] /\left[\sigma_{L} \cdot(1-\varepsilon)^{2}\right] も$ 修正キャピラリー数(一)である。

動的ホールドアップ (初期湿潤充填層 $(\mathrm{I}-\mathrm{SB})$ ),

$$
\mathrm{H}_{\mathrm{d}(\mathrm{I}-\mathrm{SB})}(\%)=100 \cdot 6 \cdot \mathrm{Re}_{\mathrm{m}}^{0.7} \cdot \mathrm{Ga}_{\mathrm{m}}^{-0.48} \cdot C p_{s}^{0.1} \cdot N c^{0.65}
$$

ここで, $\operatorname{Re}_{\mathrm{m}}=\left[\rho_{l} \cdot V_{l} \cdot D_{p}\right] /\left[(1-\varepsilon) \cdot \mu_{L}\right]$ は修正レイノルズ数 $(-), \mathrm{Ga}_{\mathrm{m}}=\left[\left(\rho_{L}\right)^{2} \cdot g \cdot\left(D_{p}\right)^{3}\right] /\left[\left(\mu_{L}\right)^{2} \cdot(1-\varepsilon)^{3}\right]$ は修正ガリレイ数 $(一), \mu_{I}$ は液体の粘性係数 $(\mathrm{Pa} \cdot \mathrm{s})$ である。

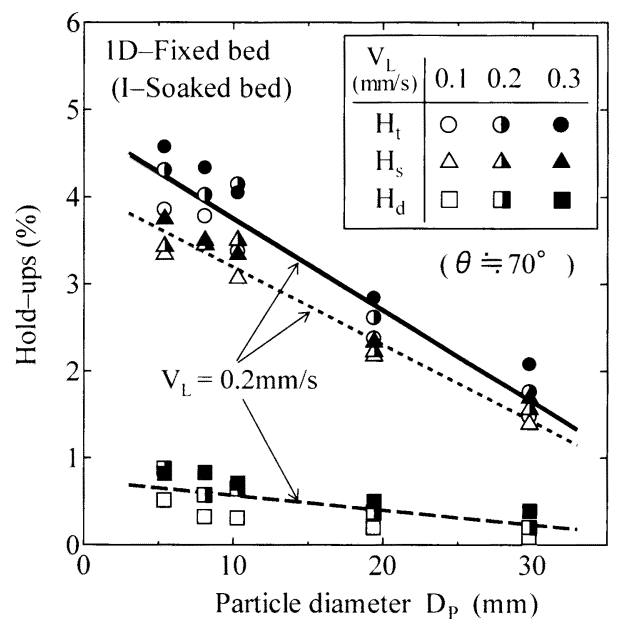

Fig. 9. Comparison between experimental and estimated hold-ups in initially soaked bed.

全ホールドアップは $\mathrm{H}_{\mathrm{S}}$ と $\mathrm{H}_{\mathrm{d}}$ の和である。

$\mathrm{H}_{\mathrm{t}}(\%)=\mathrm{H}_{\mathrm{S}}+\mathrm{H}_{\mathrm{d}}$

Fig. 9は, 初期湿潤充填層における濡れにくい系 $\left(\theta \fallingdotseq 70^{\circ}\right)$ での液ホールドアップの実験值 ${ }^{10)}$ と上式 $(2)$, (3),（4)から計算した推算值との比較を表している。网 中の実線, 点線および破線は $V_{L}=0.2 \mathrm{~mm} / \mathrm{s}$ の場合の $\mathrm{H}_{\mathrm{t}}, \mathrm{H}_{\mathrm{S}}$ および $\mathrm{H}_{\mathrm{d}}$ である。各ホールドアップの実験值と計算值は どの $D_{p}$ においても良く一致している。

$4 \cdot 1 \cdot 2$ 初期乾燥充填層における液ホールドアップの推算 式

本研究では, 初期乾燥充填層における液ホールドアップ の推算式を以下のように導出した。上述したように，初期 乾燥充填層における $\mathrm{F}_{\mathrm{C}}$ は $\theta$ と $d_{1}$ の影響を強く受ける。ま た, 濡れやすい系における充填層内の液流路の数は濡れに くい系の数よりかなり少ない（Fig. 3，4参照）。さらに， 濡れやすい系の液滴は, 粒子間の空隙や粒子表面に滞留し 難く，液体が互いにその表面張力で引つ張り合いながら数 少ない液流路に集中して素早く流下する。したがって，濡 れにくい系の静的ホールドアップと比較した濡れやすい系 の静的ホールドアップの減少率は, 濡れにくい系の液流路 の数と比較した濡れやすい系の液流路の減少率よりも大き い。これらのことから, 初期乾燥充填層における各液ホー ルドアップは $\mathrm{F}_{\mathrm{C}}$ と $\theta$ の影響を強く受けると考えられる。

本研究では, 静的ホールドアップ $\mathrm{H}_{\mathrm{S}(1-\mathrm{UB})}$ と動的ホール ドアップ $\mathrm{H}_{\mathrm{d}(\mathrm{I}-\mathrm{UB})}$ を, 以上の結果および著者らの多数の液 ホールドアップの測定值 ${ }^{9,10)}$ を用いて, 回帰解析により以 下のように導出した。

静的ホールドアップ (初期乾燥充填層 $(\mathrm{I}-\mathrm{UB})$ )

$\mathrm{H}_{\mathrm{S}(\mathrm{I}-\mathrm{UB})}(\%)=0.9 \cdot \mathrm{H}_{\mathrm{S}(\mathrm{I}-\mathrm{SB})} \cdot \mathrm{F}_{\mathrm{C}}^{0.8} \cdot N c_{m}^{-1}$

動的ホールドアップ（初期乾燥充填層(I-UB)）

$\mathrm{H}_{\mathrm{d}(\mathrm{I}-\mathrm{UB})}(\%)=0.9 \cdot \mathrm{H}_{\mathrm{d}(\mathrm{I}-\mathrm{SB})} \cdot \mathrm{F}_{\mathrm{C}}^{0.5}$ 
全ホールドアップは $\mathrm{H}_{\mathrm{S}}$ と $\mathrm{H}_{\mathrm{d}}$ の和である。

$\mathrm{H}_{\mathrm{t}}(\%)=\mathrm{H}_{\mathrm{S}}+\mathrm{H}_{\mathrm{d}}$

ここで， $N c_{m}=1+(\cos \theta)^{3}$ であり，添え字 I-SB と I-UB はそ れぞれ初期湿潤充填層および初期乾燥充填層での值である ことを表している。

本研究において, 初期乾燥充填層における液ホールド アップの推算式を導出するために用いたチャネリングファ クター $\mathrm{F}_{\mathrm{C}} に は$, 液密度や粘度の影響が十分には考慮され ていない。より正確な液ホールドアップの推算式を導出す るためには，さらなる実験の積み重ね，特に液密度の依存 性を熟考した $\mathrm{F}_{\mathrm{C}}$ の導出を行わなければならない。

\section{$4 \cdot 2$ 初期乾燥充填層における液ホールドアップの実験值 と推算値との比較}

Fig.10に，初期乾燥充填層における $\theta \fallingdotseq 70^{\circ}$ の場合の液 ホールドアップに及ぼす $V_{L}$ の依存性を示したが, $D_{p}=$ $5.4 \mathrm{~mm}$ に対する各液ホールドアップの実測值と本推算值 (実線, 点線, 破線）および $D_{p}=29.8 \mathrm{~mm}$ に対する各液 ホールドアップの実測值と本推算值（実線, 点線, 破線) は良く一致していることが分かる。

また, Fig.11には初期乾燥充填層における液ホールド アップに及ぼす濡れ性の影響を示したが，本推算式を用い た計算值 (実線, 点線, 破線) は $\theta=10^{\circ}$ と $70^{\circ}$ の両接触角 の液ホールドアップの実測值 $\left(D_{p}=10.3 \mathrm{~mm}\right)$ を良く再現し ていることが分かる。

$4 \cdot 2 \cdot 1$ 本推算值とホットモデル実験值との比較

Husslage $1^{13}$ は, 実験室規模のホットモデル実験（温度 $1550^{\circ} \mathrm{C}$, 内径 $60 \mathrm{~mm} \times$ 高さ $175 \mathrm{~mm}$ の充填層, $8 \sim 10 \mathrm{~mm}$ の コークス充填粒子，スラグは高炉スラグ組成を模擬 $[\mathrm{FeO}$ なし], 溶銑は C 飽和）により溶融スラグと溶銑の液ホー ルドアップを測定し，「溶融スラグ，溶銑ともに静的ホー ルドアップは1〜5\%の範囲であり，動的ホールドアップは 低い值である」であることを示した。また佐々ら ${ }^{14)} も$ 同様 なホットモデル実験（温度 $1500{ }^{\circ} \mathrm{C}$, 内径 $60 \mathrm{~mm} \times$ 高さ 80 $\mathrm{mm}$ の充填層， 11 13 mmのコークス充填粒子，スラグは 高炉スラグ組成を模擬［FeOなし）により液ホールド アップを測定し，全ホールドアップ，静的ホールドアップ 扩よび動的ホールドアップは, $\mathrm{CaO} / \mathrm{SiO}_{2}$ が1.1より低い場 合，それぞれ約 $3.7 ， 0.7$ と $3.0 \%$ であると報告している。 この測定值に関して，一般的に静的ホールドアップの方が 動的ホールドアップよりも大きいことから, 静的ホールド アップの $0.7 \%$ と動的ホールドアップの $3.0 \%$ の測定值は逆 ではないかと考えられる。

本推算式(4),（５)，（６）から計算した全ホールドアッ プ, 静的ホールドアップ, 動的ホールドアップは, それぞ れ $3.6 ， 3.0$ と $0.6 \%$ となる。ただし，用いた条件および物 理值 ${ }^{10.13)}$ は $D_{p}=10 \mathrm{~mm}, \mathrm{~T}=1550^{\circ} \mathrm{C}, \varepsilon=0.4, \theta=105^{\circ}, \mu_{L}=$ $0.34 \mathrm{~Pa} \cdot \mathrm{s}, \rho_{l}=2600 \mathrm{~kg} / \mathrm{m}^{3}, \sigma_{L}=0.42 \mathrm{~N} / \mathrm{m}$ である。本推算式

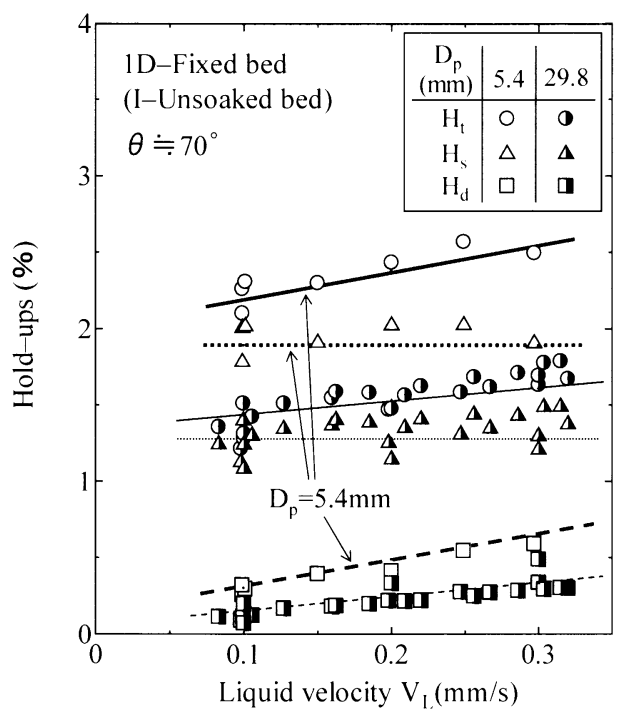

Fig. 10. Comparison between experimental and estimated hold-ups in initially unsoaked bed (influence of particle diameter)

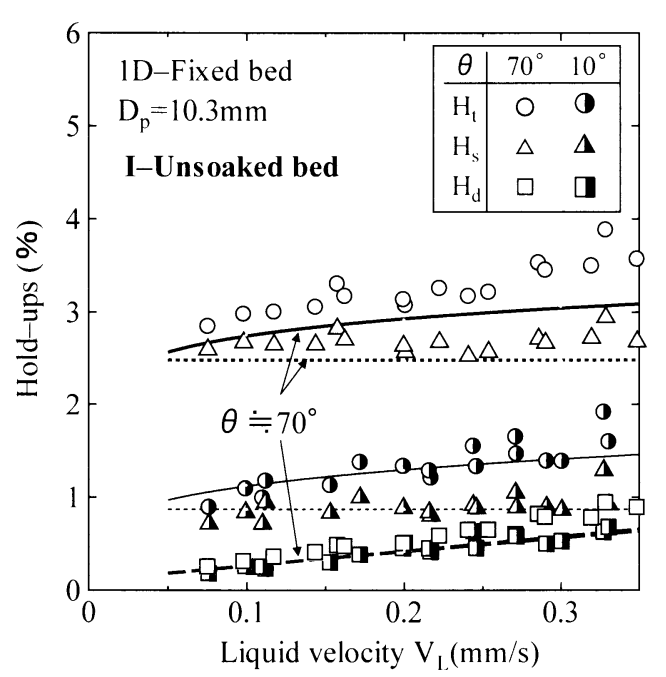

Fig. 11. Comparison between experimental and estimated hold-ups in initially unsoaked bed (influence of particle/liquid wettability).

から計算した各ホールドアップ值とホットモデルの実験 值 ${ }^{13,14)}$ とは比較的一致していると思われる。

$4 \cdot 2 \cdot 2$ 初期乾燥充填層における液ホールドアップに及 ぼす2層充填構造の影響

粒子径の異なる $2 つ の$ 充填層の積層順を変化させて, 初 期乾燥充填層における液ホールドアップおよび液流れ挙動 に及ぼす2層充填構造の影響を調べた。2層充填層におけ る可視化実験はFig. 1 に示した2Dモデルを用いて，液ホー ルドアップの測定は1Dモデル（内径 $200 \mathrm{~mm} \times$ 高さ 500 $\mathrm{mm}$ の充填層 ${ }^{10)}$ ) を用いて行った。

Fig.12に示したように（初期乾燥充填層， $\theta \fallingdotseq 65^{\circ}$ の場合）. 下層に $D_{p}=10.3 \mathrm{~mm}$ の粒子を積み, その上に $D_{p}=5.0 \mathrm{~mm}$ の 粒子を積み上げた場合(U5-L10)とその逆の順に粒子を積み 上げた場合(U10-L5)の液流れ挙動は全く異なる。 

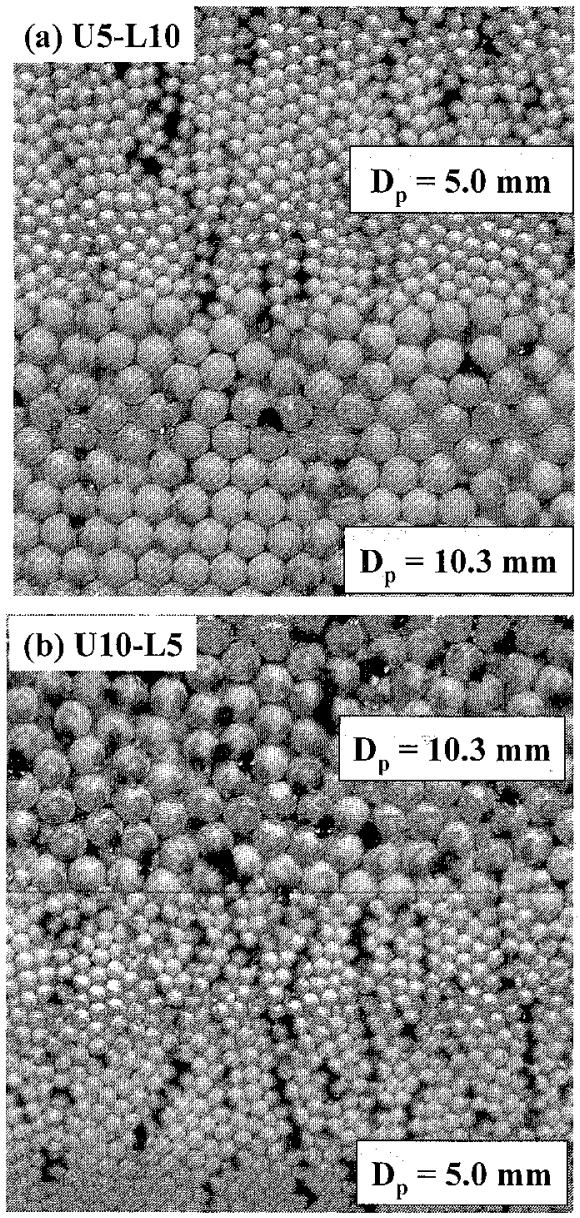

Fig. 12. Visualization of liquid flow behavior through two layer bed packed with different particle diameters in initially unsoaked bed $\left(\theta \fallingdotseq 65^{\circ}\right)$.

(b) U10-L50場合，10 mm 球粒子充填層を流下寸る液滴 は充填層全体に広がっている。また，5 mm球粒子充填 層を流下する液は特定の流路を流れるチャネリングフ ロー7,10)形成し，それぞれの液流れ挙動は，単一の大き さの粒子充填層の場合と同じである (Fig. 3参照)。ところ が，(a) U5-L10の場合，下層の $10 \mathrm{~mm}$ 球充填層に打ける液 流路の数は上層の $5 \mathrm{~mm}$ 球充填層の液流路の履歴を引き継 ぎ，特定の流路を流れるチャネリングフローが形成されて いる。このように初期乾燥充填層の場合，下層に液滴が均 一に広がりやすい大粒子を充填していたとしても，その チャネリングファクター $\mathrm{F}_{\mathrm{C}}$ は上層の $\mathrm{F}_{\mathrm{C}}$ の影響を強く受け る。

初期乾燥 2 層充填層（濡れにくい系： $\theta \fallingdotseq 70^{\circ}$ ）における 液ホールドアップに及ぼす $V_{L}$ の依存性をFig.13に示す。 U5-L10（下層に $D_{p}=10.3 \mathrm{~mm}$ の粒子を $250 \mathrm{~mm}$ の高さまで 積み，をの上に $D_{p}=5.0 \mathrm{~mm}$ の粒子を $500 \mathrm{~mm}$ の高さまで程 み上げた場合）の $\mathrm{H}_{\mathrm{t}}$ と $\mathrm{H}_{\mathrm{S}}(\mathrm{O}, \triangle)$ はU10-L5（5.0 mm球が下 で $10.3 \mathrm{~mm}$ 球をその上に積み上げた場合，すなわちU5-L 10

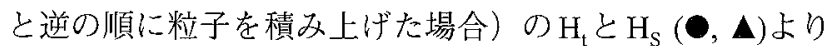
も小さな值である。本推算式 (4), (5)，(6)から計算し た各ホールドアップ（実線, 点線, 破線）はU5-L10およ

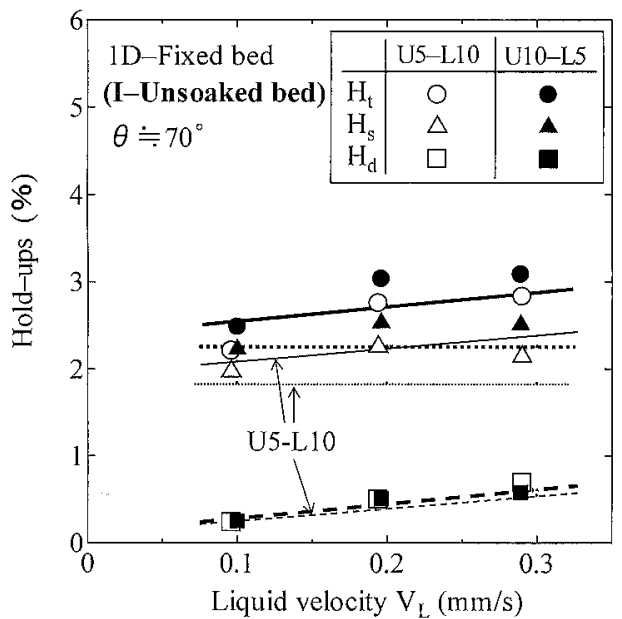

Fig. 13. Comparison between experimental and estimated hold-ups under initially unsoaked bed (influence of packing order of two layer bed packed with different particle diameters).

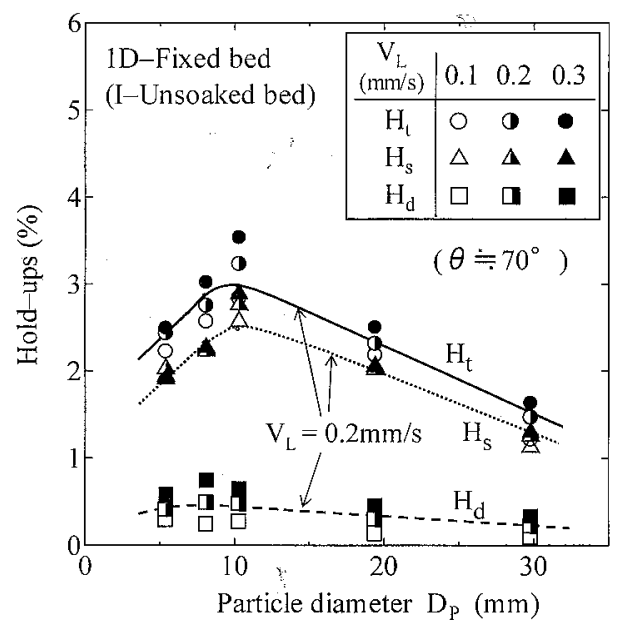

Fig. 14. Comparison between experimental and estimated hold-ups in initially unsoaked bed (influence of particle diameter).

びU10-L5それぞれにおける実測值と比較的一致している。 ただし，U10-L5の場合は $5 \mathrm{~mm}, 10 \mathrm{~mm}$ 単一の大きさの球 充填層に打けるそれぞれの $\mathrm{F}_{\mathrm{C}}$ を用い，U5-L10の場合，下 層の $10 \mathrm{~mm}$ 球充填層の $\mathrm{F}_{\mathrm{C}}$ は $5 \mathrm{~mm}$ 球充填層の $\mathrm{F}_{\mathrm{C}}$ と同じ值で あると仮定して簡易計算した。

$4 \cdot 2 \cdot 3$ 初期乾燥充填層における液ホールドアップに及 ぼす充填粒子径の影響

濡れにくい系 $\left(\theta \fallingdotseq 70^{\circ}\right)$ の初期乾燥充填層に扎いては， Fig.14に示すように，どの $V_{L} に お い て も H_{t}$ と $\mathrm{H}_{S}$ は $D_{p}$ の減 少とともに增加し， $D_{p} \fallingdotseq 10 \mathrm{~mm}$ 付近で最大値を取る。さら に $D_{p}$ が減少すると比表面積がさらに増加するにも関わら ず $\mathrm{H}_{\mathrm{t}}$ と $\mathrm{H}_{\mathrm{S}}$ が急激に減少する特異な現象を示している10)。 本推算式 (4)，(5)，(6)から計算した $V_{L}=0.2 \mathrm{~mm} / \mathrm{s}$ に打け る $\mathrm{H}_{\mathrm{t}}$ を央線で, $\mathrm{H}_{\mathrm{S}}$ を点線で, $\mathrm{H}_{\mathrm{d}}$ を破線で $D_{p}$ に対して示し ている。本推算式で計算した $H_{t}, H_{S}$ および $H_{d}$ は，実測値 と良く一致し, 特に $\mathrm{H}_{\mathrm{t}}$ と $\mathrm{H}_{\mathrm{S}}$ が $D_{p} \fallingdotseq 10 \mathrm{~mm}$ 付近で急激に変 
化する特異な現象も良く再現している。

\section{5. 結論}

初期乾燥充填層における液ホールドアップを推算するた めに、新たにチャネリングファクター $\mathrm{F}_{\mathrm{C}}$ を提案し， CCD

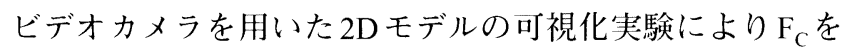
求めた。この $\mathrm{F}_{\mathrm{C}}$ と著者らの多くの液ホールドアップデー タの回帰解析から液ホールドアップの推算式を導出し, 本 推算值と種々の実測值とを比較した。本研究から得られた 結果をまとめると以下のようになる。

(1) 濡れやすい系に打ける液滴は物理的に粒子表面に 広がりやすいにも関わらず, 初期乾燥充填層の層頂から充 填層に均一分散した液滴は, 充填層全体には広がらずに局 所的な流路を形成しながら特定の場所を流下する。

（2）初期乾燥充填層におけるチャネリングファクター $\mathrm{F}_{\mathrm{C}}$ は以下のように表される。

$$
\mathrm{F}_{\mathrm{C}}=1-\exp \left(-C p^{0.75} / N c^{3.5}\right)
$$

ここで, $C p^{\prime}=\left[\rho_{L} \cdot g \cdot\left(d_{\mathrm{r}}\right)^{2} / \sigma_{L}\right]$ は修正キャピラリー数 $(-)$, $N_{C}=1+\cos \theta$ は無次元界面力 $(-), d_{v}=[\varepsilon /(1-\varepsilon)]^{1 / 3} \cdot D_{p}$ は平均 空隙徍 $(\mathrm{m}), g$ は重力加速度 $\left(\mathrm{m} / \mathrm{s}^{2}\right), \rho_{L}$ は液体の密度 $\left(\mathrm{kg} / \mathrm{m}^{3}\right)$, $\sigma_{L}$ は表面張力 $(\mathrm{N} / \mathrm{m}), \theta$ は固液接触角 $(\mathrm{deg}), \varepsilon$ は空隙率 $(-)$ である。

（3）初期乾燥充填層におけ年争的 $\mathrm{H}_{\mathrm{S}(1-\mathrm{UB})}$, 動的 $\mathrm{H}_{\mathrm{d}(1-\mathrm{UB})}$, 全ホールドアップ $\mathrm{H}_{\mathrm{t}}$ は以下の式で推算できる。

$$
\begin{aligned}
& \mathrm{H}_{\mathrm{S}(1-\mathrm{UB})}(\%)=0.9 \cdot \mathrm{H}_{\mathrm{S}(1-\mathrm{SB})} \cdot \mathrm{F}_{\mathrm{C}}^{0.8} \cdot N c_{m}^{-1}, \\
& \mathrm{H}_{\mathrm{d}(1-\mathrm{UB})}(\%)=0.9 \cdot \mathrm{H}_{\mathrm{d}(1-\mathrm{SB})} \cdot \mathrm{F}_{\mathrm{C}}^{0.5}, \\
& \mathrm{H}_{\mathrm{t}}(\%)=\mathrm{H}_{\mathrm{S}}+\mathrm{H}_{\mathrm{d}}
\end{aligned}
$$

ここで, $N c_{m}=1+(\cos \theta)^{3}$ であり，添え字 I-SB と I-UBはそ
れぞれ初期湿潤充填層および初期乾燥充填層での值であ る。

（4）本推算式から計算した液ホールドアップは，粒子 径あるいは接触角に関わらず, 初期乾燥充填層における実 測值と良く一致する。

（5）初期乾燥充填層において，単一の大きさの粒子充 填層の液流れ挙動と異なる場合の2 層充填層の液ホールド アップの実測值も本推算式で良く再現できる。

本研究を遂行するに当たり貴重な討論・ご助言を頂いた 名古屋大学 工学研究科助教授 坂東博士, JFE スチール （株）主任研究員 佐藤博士，新日本製鐵（株）主任研究

員 篠竹博士に感謝いたします。

\section{文献}

1) T.K.Sherwood, G.H.Shipley and F.A.L.Holloway: Ind. Eng. Chem., 30 (1938), 765.

2 ) A.Mersmann: Chem. Inf.-Technol., 37 (1965), 218.

3 ) T.Fukutake and V.Rajakumar: Trans. Iron Steel Inst. Jpn., 22 (1982), 355.

4 ) A.Alidilar, A.Bicer and A.Murathan: Chem. Eng. Commun., 128 (1994), 95.

5 ) J.Yagi: ISIJ Int., 33 (1993), 619.

6 ) G.S.Gupta and S.Bhattacharyya: ISIJ Int., 43 (2003), 1927.

7 ) W.M.Husslage, T.Bakker, A.G.S.Steeghs, R.H.Heerema and M.A.Reuter: 6th World Cong. on Chem. Eng. 2001, Melbourne, (Sep. 2001), 1643 (CD-ROM), AIChE, New York.

8 ) T.Usui, H.Kawabata and F.Fujita: CAMP-ISIJ, 16 (2003), 792.

9 ) T.Usui, H.Kawabata, T.Sogo, S.Morii, M.Ichida and Z.Morita: Tetsuto-Hagané, 82 (1996), 899.

10) H.Kawabata, Z.Liu, F.Fujita and T.Usui: ISIJ Int., 45 (2005), 1466.

11) M.Li, Y.Bando, T.Tsuge, K.Yasuda and M.Nakamura: Chem. Eng. Sci., 56 (2001), 5969.

12) M.Li, Y.Bando, T.Tsuge, K.Suzuki, K.Yasuda and M.Nakamura: J. Chem. Eng. Jpn., 33 (2000), 211

13) W.M.Husslage: Doctoral Thesis, Delft University of Technology, Netherlands, (2004), 118.

14) Y.Sassa, K.Tanaka, Kouno and Fukuda: Tetsu-to-Hagané, 73 (1987), $\mathrm{S} 842$ 